\title{
Social Capital and Stratification of Young People
}

\author{
Alireza Behtoui ${ }^{1,2}$ \\ ${ }^{1}$ Institute for Migration, Ethnicity and Society (REMESO), Department of Social and Welfare Studies, \\ Linköping University, 60174 Norrköping, Sweden \\ ${ }^{2}$ Department of Social Anthropology, Stockholm University, Universitetsvägen 10, 11418 Stockholm, Sweden; \\ E-Mail: alireza.behtoui@socant.su.se; Tel.: +46 8163810; Fax: +46 8158894
}

Submitted: 12 April 2013 | In revised form: 25 June 2013 | Accepted: 31 July 2013 |

Published: 12 August 2013

\begin{abstract}
This paper addresses the impact of social capital on the status attainment process of young people at the start of their careers and examines how social class, gender and ethnicity affect the accumulation of social capital and thereby labour market stratification of young people. A sample of young Swedes graduating from vocational schools and universities between 2005 and 2006, was surveyed via the telephone about their experiences acquiring jobs. Two research questions are posed: (i) Which characteristics (class, gender and ethnicity) affect young people's access to more social capital? (ii) How is social capital rewarded in the labour market? The results show that being female, coming from the lower social classes and being a member of a stigmatized immigrant groupare associated with a substantial social capital deficit. When socioeconomic and demographic backgrounds as well as the human capital of respondents are controlled, social capital is positively associated with salary level. The results indicate that social capital is a significant factor in the stratification process of young people.
\end{abstract}

Keywords: education; occupation; social capital; young people

\section{Introduction}

Proponents of the meritocratic approach argue that, when societies evolve from traditionalism to industrialism, the criteria of 'achievement' necessarily replace the criteria of 'ascription' in all forms of social selection. Merit, defined as ability plus effort, shown through one's formal educational achievements and labour market experience, is the criterion used for allocating individuals to different positions. Consequently, what you can do rather than who you are (as defined by your class, gender or ethnicity/race) is the factor determining your position in the social hierarchy [1]. In more recent models of status attainment, education is seen as the mediating factor between socioeconomic background and labour market outcomes such as salary or occupational status. As empirical findings demonstrate, educational achievements are strongly dependent on ascribed resources (for Sweden, see [2]).

In status attainment research, less attention has been paid to social processes in the more informal private spheres of life (such as friendship, partnership and neighbourhood) that lead to inequalities. More precisely, how being embedded in resource-poor social 
networks and consequently having less access to social capital may negatively affect individuals' educational attainment and labour market outcomes. Studies which incorporate social capital as an additional factor to explain social status have shown that 'when the mediated effects of parental status through social capital are taken into account, ascribed status might be just as important, if not more so, than achieved status' ([3], p. 165).

To investigate the impact of social capital on the labour market stratification process, this study, conducted in Sweden, uses data on the job-entry process of a group of young people who completed their studies in 2005-2006 and started working. These data have the advantage of focusing on social capital in the first phase of the individuals' working lives, when social capital is more ascribed than achieved, that is, when strong kinship and social origin ties, rather than workrelated ones, are more important [4]. On the other hand, the data have the disadvantage that they contain information about the wages of young people (as a proxy for their status attainment) only at the start of their careers, while in many cases the biggest steps in occupational careers are taken later, such as when people leave their first jobs and take up new ones.

Most prior research on the effect of social capital on stratification processes was conducted in countries with unregulated labour markets, such as United States (for a review see [5]). It seems likely that resources in one's social networks may play a greater role in these countries than in a highly regulated market such as that of Sweden, which has a nationwide system of public employment agencies, with at least one office in each municipality. The National Labour Market Board regularly publishes information about job openings. Furthermore, employers in Sweden are required by law to report vacancies to employment offices. Considering these characteristics, the question is; given the same educational achievements, can we detect differences between the quality of jobs obtained by young people at the start of their careers dependent upon access to more social capital?

Furthermore, active membership of civic associations has traditionally been a well-known avenue for social mobility of young people from lower class backgrounds in Sweden $([6]$, p. 300). If we assume that membership of such associations is a source of social capital and that such membership "could offset some of the impact of social and economic disadvantages" ([7], p. 18), then the Swedish context could provide an interesting case study in this area.

To investigate the impact of social capital on the labour market positions of young people at the start of their careers, the following research questions are posed:

1. Which characteristics of young people (such as socioeconomic background, educational level, gender, birthplace and marital status) enhance or hinder access to social capital? Or, who has better, and who has worse, access to social capital?

2. How well is social capital rewarded in the labour market?

\section{Theoretical Framework}

According to neoclassical economics (which focuses on the optimizing individual agent which has much in common with the meritocratic approach), workers are paid according to their productivity, and a worker's productivity depends on the quality and quantity of 'human capital' an individual has acquired through formal education and/or professional training [8].

As earlier empirical studies demonstrated, there is a strong correlation between social origin and academic achievement (for school-mediated modes of reproduction of the social structure, see [9]). Besides, in the labour market the full economic and social rewards of education depend on social capital [10]. People with strong educational credentials have the potential to obtain higher status jobs, but if they are not born into higher social groups and/or lack the 'proper' contacts, they cannot obtain a full return on their education. Social capital 'procures a competitive advantage by providing higher return on investment' ([11], p. 195).

Social capital has been defined on both the micro (individual) and the macro (collective) levels, with consequent theoretical and methodological developments on two different tracks ([12], p. 3). Putnam, the most cited author in social capital research, is the central representative of the first type, i.e. research in which the unit of analysis is the community, the region or the entire nation ([12], p. 3).

The concept of social capital applied at the micro or individual level has been defined differently in various fields. Coleman's definition of social capital stresses its social control function and is mainly used within the field of educational research. Coleman's chief interest has been the effects of social capital in creating human capital, in the family and in the community [13].

Researchers who come close to Bourdieu's definition of social capital [14] emphasize instead the advantages which individuals accrue as a result of connections with others in their network who may help them with advice, further connections, information, loans, and so on for 'access to employment, mobility through occupational ladders, and entrepreneurial success' ([15], p. 12). In this research tradition, social capital deals with the process of production and reproduction of social inequality in the labour market, and is defined as a resource accumulated as a result of historical relations of power. Accordingly, the probability of accumulating and maintaining social capital increases in proportion to the amount of economic and cultural capital in the individual's network [16]. Lin [17] and his colleagues, link social status to social resources in the individual's net- 
work, and emphasize that the very potency of one's network depends, above all, on the position that one occupies in the social hierarchy.

A central claim of this research tradition concerns conflict and power. In the labour market, for example, one's position depends not only on whether one fulfils the formal educational demands of a job, but also on how one stands relative to other applicants in terms of other requirements [18]. As a result, one group's social capital gain may mean another group's social capital loss [19].

Those who are connected to better-placed individuals have access to better information about job openings. Such connections offer greater influence and higher social credentials, as, for example, when wellplaced contacts are cited as referees in a job-seeker's application [16]. In some cases powerful network members can also create a position for someone [20]. Network members may reinforce identification, act as role models and enhance the job-seeker's confidence and self-esteem. As Brown et al. [21] put it, 'people will not only tend to limit the range of jobs they apply for to the jobs they feel (correctly or otherwise) they have a chance of getting, but also to what they think is appropriate'. Finally, network connections can provide emotional and instrumental support, which contributes to an individual's physical and mental wellbeing [22].

Drawing on Bourdieu's discussion of the concept of social capital [14], one can argue that social capital is manifested in different states: embodied, objectified or institutionalised. As Denord François et al. ([23], p. 91) put it, 'in reality these states are intertwined in various ways'. On embodied social capital Bourdieu writes ([14], p. 109): 'Manners (bearing, pronunciation, etc.) may be included in social capital insofar as, through the mode of acquisition they point to, they indicate initial membership of a more or less prestigious group'. Through participant observation in selection interviews for recruitment, Jenkins [24] coins the concepts of 'acceptability' and 'employability' which indicate this state of social capital [25].

Objectified social capital is group or network membership and to operationalise it Bourdieu ([14], p. 103) suggests measuring 'the size of the networks of connections as well as the volume of the capital (economic, cultural, or symbolic) possessed by connections'. There are several methods of assessing resources in an individual's social network. The 'position generator' method employed in this study is more commonly used in research on occupational attainment and getting desirable labour market outcomes (such as higher occupational prestige or wages). Using this method, researchers choose a sample of occupations from the full range of the hierarchical structure of society (from very low to high prestige). Respondents are asked if among their acquaintances, close friends or relatives, there is anyone who has one of the jobs indicated on a list. By mapping these ties (both weak and strong), this method explores the entire network. Under this method, the occupations of contacts are assumed to reflect important aspects of their social location, such as their power, class background and educational status. Another approach for measuring the objectified state of social capital is the 'name generator' method which can provide a rich record of a small number of closer relationships of respondents [26]. This method is very useful for some research purposes such as studying the outcomes of social capital in work organization (for discussion about these methods see Lin and Erickson [27]).

The institutionalized state of social capital consists of formalised contact patterns and active membership of political, religious and civic organizations, which 'guarantees a particular form of social relationship in a lasting way' ([14], p. 105). Such activity enables individuals to obtain resources that are sometimes beyond the family environment. Particularly if they are members of a subordinate group, using the 'collective resources' of organizations compensates for disadvantaged backgrounds ([28], p. 119). Active membership of unions and political parties in the left bloc in Sweden, for example, has been a well-known avenue for enhancing the careers of people with a working-class background ([6], p. 300). As Arneil [29] suggests, despite the exclusionary practices of the mainstream organizations of dominant groups, when subordinate groups begin to organize themselves and become agents in civic associations, they can (through, among other things, socialcapital building) challenge the basic premises of the current balance of power (see also [30]).

In addition, as Wang ([31], p. 22) mentions, activity in voluntary organisations can signal to a prospective employer young people's attitudes to 'responsibility', and their aim of increasing 'social skills' and obtaining knowledge 'not learned in a classroom' (see also [18]).

\section{Previous Research}

Granovetter's Getting a Job [20] showed that finding jobs through informal job-search methods (i.e. via social networks) is very common and important. Further development in this field is associated with Nan Lin [32], whose 'social resource theory' holds that networks themselves are not the same as social resources. In other words, using social networks per se provides no relative advantages in the competition for better jobs [17]. In the first stage of the development of social resource theory, the composition of a network and the resources accessible through it were measured by the occupational standing of the contact (activated to locate the job), on the assumption that using highly prestigious contacts was linked to higher wages or higher-status occupations. Further research led to a relaxation of the assumption that 'a particular contact in the job-search process is the same as "social resources"'. Social resources, Lin [16] suggested, can improve one's labour market outcomes even if 
one does not find a job through social networks (see also Lin and Erickson [33]). Consequently, the focus shifted from the use of personal contacts in general (and a specific contact in particular) to the pool of resources embedded in a job-seeker's social network. The quality of the job obtained should be linked to social resources in the individual's network, regardless of the job-finding methods used and of whether or not a specific contact has been involved [16]. Reviews of numerous studies show that access to social capital provides occupational gains (for a review see Lin and Erickson [27]).

Substantive empirical studies have examined the role of credentials ('human capital') in the job-obtaining processes of young people. However, as Cain [34] demonstrates, labour market studies within the frame of 'human capital' theory can explain only a small percentage of the variation in wages and labour market positions of individuals from different groups.

Even though scholars have mentioned that social capital is important specifically for young people who are dealing with the transition from school to work [35], there are not many studies which use quantitative data to examine the impact of social capital at the beginning of a person's working life. Flap and Boxman [4] studied 365 graduates from higher vocational training in the Netherlands. They showed that young people more often search for jobs informally when they possess more social capital (measured by position-generating and name-generating methods) and this has a significant impact on their incomes. Jokisaaria and Nurmib [36] studied 409 graduates from polytechnic schools in Finland. They measured respondents' social capital against the people with whom they had discussed important matters related to their personal work goal and demonstrated that the higher the status of the social contacts, the higher their job status and job satisfaction was. Using the same dataset, Jokisaari [35] examined whether supervisor-level or employee-level ties before getting a job are related to the social integration of respondents when they enter an organisation. The results confirm the hypothesis. Wang [31], using a sample of 2,971 students from the National Education Longitudinal Study, (U.S. Department of Education, NELS: $88 / 00)$, reported that social capital in college, measured in terms of participation in extracurricular activities and participation in voluntary organisations, played a significant and positive role in getting students a more satisfying job and a higher salary.

\section{Data}

The data for this study were gathered via a telephone survey carried out in 2009-2010. Interviews lasted approximately 20-25 minutes each. Different groups of young people who graduated in 2005-2006 from vocational schools and universities were asked about their experiences in looking for employment. Through this design it was possible to study the rate of return on investment in education for young people with different life experiences.

Young people in the first group graduated from vocationally-oriented secondary school programmes [37]. The programmes that are included in this kind of education are the following: (i) Hotel, restaurant and catering (Hotell och Restaurangprogrammet), (ii) Health and nursing (Omvårdnadsprogrammet), (iii) Business and administration (Handels- och Administrationsprogrammet), and (iv) Construction (Byggprogrammet). The percentages of the all the uppersecondary students in Sweden who are enrolled in these programmes are, 4.3, 3.9, 5.3 and 4.7 respectively.

Individuals in the second group are graduates from the following undergraduate programs: (i) Teacher Education, (ii) Nursing, (iii) Social Work, (iv) Social and Cultural Analysis, (v) Political Science and Economics, (vi) Business and Economics, and (vii) Culture, Society and Media Production.

The third group consists of graduates in three prestigious university programs: (i) Psychology, (ii) Master of Science in Technical Physics, and (iii) Industrial Economics and Management.

Previous studies (for example, [38]) maintain that children from privileged social groups are more likely to enrol in such prestigious courses, which are normally longer and more attractive, and require high grades for admission, than those courses selected by members of the second group (for a definition of, and discussion about the issue of prestigious courses in Swedish universities, see [39]).

Universities in Sweden are not yet ranked according to status, as they are in, for example, the USA and the UK. But certain newly established universities or university colleges can award only undergraduate degrees [40]. Respondents in the present study were selected from graduates of a traditional university in a middlesized city in Sweden. Those with vocationally-oriented secondary school qualifications were also residents of the city where the university campus is located. The quality of secondary schools with vocational programs in this city is likewise comparable with that of other schools with the same programs in others cities in the country [41]. Therefore, we can assume that our respondents are representative of undergraduate students and vocationally-oriented secondary school pupils of the country.

Because of the favourable labour market conditions in Sweden at the time, (with an unemployment rate of about 6 percent for those aged $24-45$ years and 14 percent for those aged 20-24 years), many of the young people in this study succeeded in obtaining jobs. The labour market situation in the regions where this research was carried out was among the most favourable in the country. Furthermore, the young adults in this study are mainly what Bardley and Devadson ([42], p. 123) call 'stickers', that is, those who had already selected the 'right' education and had identified 
a career objective after they ended their full-time education. In other words, on completing their full-time education (graduating from the vocational, undergraduate and prestigious courses), they are a positively selected group among young people in general.

Of the individuals on the school and university registers that we obtained for this study, 67 percent of the university-educated and 56 percent of those who completed secondary-school courses participated in the survey. About 20 percent refused to participate; the remainder (i.e. 13 and 24 percent) could not be contacted at their last known addresses or telephone numbers. Lack of time was the main reason given by the majority of those with university degrees who declined to participate in the survey. In contrast, individuals with secondary school qualifications gave no clear reason for their refusal, but we speculate that they avoided interviews because they had no secure job positions. Hence, it seems that our survey has failed to include individuals at the two extremes, that is, those with the best and the worst labour market outcomes therefore the results must be interpreted with caution.

Since respondents included very few unemployed persons, nine of them, with a secondary school education but who had never had a job, were dropped. Those few (14) individuals who were temporarily out of the labour market (on maternity or paternity leave or taking other kinds of short breaks) were asked about their most recent jobs. Furthermore, 38 individuals older than 40 years at the time of the interviews were also excluded from the final sample, because inclusion of such mature graduates might have skewed the results.

It is possible to compare the final sample of 438 individuals with the original lists only in respect of gender and, to some extent, immigrant background by their names. The final sample was highly representative in terms of gender (with a slight overrepresentation of women) but individuals with immigrant backgrounds were slightly under-represented. (Details about the representativeness of the final sample regarding the gender and immigrant background of respondents for each course are available from the author on request).

\section{Measurements}

At the different stages of this study, the following variables are included: Gender (Female) is coded female $=1$ and male $=0$. Socioeconomic background of respondents (labelled "SEB") is a composite measure and includes information on prestige scores of the occupational positions and years of education of respondents' parents. The variable is constructed by performing a factor analysis (principal component) on the aforementioned four variables (parents' educational level and occupation), and consequently is a standardized measure (mean $=0 ; \mathrm{sd}=1.0$ ).

Young people with an immigrant background in this study are individuals who have two foreign-born parents. In this category those who are native-born of foreign parentage are defined as "second generation" and those who are born abroad but have completed secondary school in Sweden are defined as "1.5 generation" [43]. In addition, two different regions of origin of individuals with immigrant backgrounds are distinguished: north-west countries (NW), which comprise north-west Europe and North America, and countries outside north-west Europe and North America (ONW), which account for rest of the world [44]. Such a distinction is based on the results of earlier Swedish studies which show that immigrants from ONW countries are in many cases residents of stigmatized neighbourhoods, are concentrated in inferior parts of the labour market, and are exposed to a higher risk of suffering from discrimination [45]. Consequently, four categories of origin are generated by country of birth in this study: SV are children of native-born parents; the $\mathrm{NW}_{2}$ group comprises children of immigrants from "north-western Europe and North America"; $\mathrm{ONW}_{2}$ and $\mathrm{ONW}_{1.5}$ are children of immigrants from countries "outside north-western Europe and North America". All individuals in our sample have completed secondary education in the Swedish educational system. ONW 1.5 is the only group whose members were born abroad. There were also five individuals from the $\mathrm{NW}_{1.5}$ group in the final sample, who were dropped.

Respondents' educational achievements are measured at three educational levels (vocationally oriented secondary school, university undergraduate and highstatus tertiary education) completed by respondents at the time of the survey. Another control variable is respondents' age (a continuous variable).

To measure the objectified state of social capital this study employs the position-generator method. A list of 21 occupations ranging from high to low in the hierarchical structure of Swedish society was developed [46]. Respondents were asked: "Of your relatives, close friends, or acquaintances, is there anyone who has a job listed in the following table?" If the response was 'yes', the respondent was asked whether she or he knew this person before searching for their current job. If a respondent knew the contact after getting their current job, the contact was dropped to make sure that the resources in the respondent's networks belonged to the period prior to getting their current job.

The following indicators are suggested as measurements of resources in the networks (objectified social capital):

(i) extensity or the number of positions (from the list of occupations ) that were attainable, reflects the diversity of positions, and their embedded resources;

(ii) upper attainability i.e., the highest status job, among contacts of the respondent, indicated the best possible resources in the social network; 
(iii) heterogeneity: the range of positions (distinction between the highest and lowest attainable positions), and

(iv) the composition of resources or average status of the contacts indicated typical resources [16].

Extensity indicates the quantity of ties that give access to occupations, while the other three characteristics indicate the quality of access or the volume of capital possessed by networked individuals. In line with earlier studies, we can assume that the variables' extensity, upper reachability, range and average were observable measures of the unobserved variable "objectified social capital" [16]. A factor analysis (with principal component methodology, varimax rotation, and a criterion of an eigenvalue equal to or greater than 1 yielded a single factor solution. Thus, a factor score based on the four indeces was constructed for each individual (see Table A1 in the Appendix).

To measure the institutionalised state of social capital of young people in this study we asked them about their active membership of civil society organizations. We presented respondents with a list of nine types of organization and asked them whether they had been an active member of: pupils' councils, political parties, student organizations, religious groups, sports associations, scout associations, charities (e.g. Amnesty, Save the Children and the Red Cross), immigrant organizations or other organizations. Membership of immigrant organizations had a positive impact neither on their access to social capital nor on their salaries, and was therefore excluded. The dummy variable "voluntary association" shows whether a respondent had been an active member of any of these organizations $(=1)$ or not $(=0)$.

\section{Results}

Table 1 and Table 2 summarize respondents' characteristics in terms of socioeconomic background, gender and immigrant background.

As is evident from Table 1 , there is a clear association between respondents' socioeconomic background (parents' education and job status) and their educational achievements. The results of estimated logistic regression models (not shown here, but available on request), demonstrated that, in line with previous studies, the probability of having a university degree or a degree from a prestigious program is strongly associated with respondents' class background; in other words, the higher the status of respondents' socioeconomic backgrounds, the greater their educational achievements.

Equally, the monthly salaries of respondents show a significant correlation with their educational levels. The average occupational status of those who are in respondents' networks (an indicator of their access to objectified social capital) and their active membership of voluntary organisations (an indicator of the state of their institutionalised social capital) are also correlated with their class background.

Table 1. Summary of sample characteristics for three educational levels, means (S.E.) or percent.

\begin{tabular}{lccc}
\hline Educational level & $\begin{array}{c}\text { Secondary } \\
\text { school }\end{array}$ & $\begin{array}{c}\text { Tertiary } \\
\text { education }\end{array}$ & $\begin{array}{c}\text { High-status tertiary } \\
\text { education }\end{array}$ \\
\hline $\mathrm{N}$ & 144 & 210 & 84 \\
$\%$ & 32.9 & 47.9 & 19.2 \\
Age & $\mathbf{2 2}(0.56)$ & $\mathbf{3 0}(3.6)$ & $\mathbf{3 0}(2.1)$ \\
Highest Edu. (Y) of parents & $\mathbf{1 2 . 8}(2.4)$ & $\mathbf{1 3 . 6}(2.6)$ & $\mathbf{1 4 . 9}(2.1)$ \\
Parents' job status & $\mathbf{3 9 . 9}(13)$ & $\mathbf{5 1 . 1}(16.6)$ & $\mathbf{5 9 . 3}(14.8)$ \\
Average job status of contacts & $\mathbf{3 7 . 4}(7.3)$ & $\mathbf{4 8 . 9}(21.7)$ & $\mathbf{5 6 . 3}(9.7)$ \\
Member of a social org. (\%) & $\mathbf{6 5}(0.47)$ & $\mathbf{8 4}(0.36)$ & $\mathbf{9 1}(0.27)$ \\
Income/month, adj. for working & $\mathbf{1 9 , 7 1 2}(4,366)$ & $\mathbf{2 3 , 7 7 8}(3,624)$ & $\mathbf{3 5 , 2 6 2}(5,531)$ \\
Hours, Swedish Crown (SEK) & & & \\
\hline
\end{tabular}

Note: The means tests indicate a significant difference between groups at $1 \%$ level. ANOVA and post hoc tests show that the differences between three groups concerning all means are statistically significant at $5 \%$ level. 
Table 2. Summary of sample characteristics on the subject of gender and origin, percent or means (standard deviation).

\begin{tabular}{|c|c|c|c|c|c|c|}
\hline & \multicolumn{4}{|c|}{ Origin } & \multicolumn{2}{|l|}{ Gender } \\
\hline & SV & $\mathrm{NW}_{2}$ & $\mathrm{ONW}_{2}$ & $\mathrm{ONW}_{1.5}$ & Men & Women \\
\hline $\mathrm{N}$ & 348 & 29 & 21 & 40 & 163 & 275 \\
\hline Mean years of parents' education & 13.7 & 13.5 & 12.9 & 13.3 & 13.9 & 13.4 \\
\hline Mean job status of parents & 50.3 & 48.4 & 43.9 & 41 & 49.6 & 48.6 \\
\hline Years of education & 14.8 & 14.8 & 14.02 & 14.1 & 14.7 & 14.7 \\
\hline With tertiary school education (\%) & 70 & 69 & 52 & 50 & 62.3 & 71 \\
\hline High-status tertiary education (\%) & 21.6 & 21 & 9.5 & 2.5 & 33.5 & 12 \\
\hline Member of a social org. (\%) & 80 & 79.3 & 71.4 & 75 & 79 & 79 \\
\hline $\begin{array}{l}\text { Average job status of contacts } \\
\text { (std.deviation) }\end{array}$ & $\begin{array}{c}47.7 \\
(18.6)\end{array}$ & $\begin{array}{c}49.6 \\
(12.7)\end{array}$ & $\begin{array}{c}42.9 \\
(10.7)\end{array}$ & $\begin{array}{c}36.3 \\
(8.07)\end{array}$ & $\begin{array}{l}49.6 \\
(24.9)\end{array}$ & $\begin{array}{c}44.7 \\
(10.8)\end{array}$ \\
\hline $\begin{array}{l}\text { Income/month, adj. for working } \\
\text { hours, SEK (std.deviation) }\end{array}$ & $\begin{array}{l}24,553 \\
(6,202)\end{array}$ & $\begin{array}{l}24,137 \\
(5,943)\end{array}$ & $\begin{array}{l}22,309 \\
(6,046)\end{array}$ & $\begin{array}{l}20,725 \\
(4,358)\end{array}$ & $\begin{array}{l}26,245 \\
(6,883)\end{array}$ & $\begin{array}{l}22,778 \\
(5,230)\end{array}$ \\
\hline
\end{tabular}

Note: The means tests indicate a significant gender difference at $1 \%$ level for variables 'income' and 'status of contacts'. ANOVA and post hoc tests, show that the mean differences between ONW ${ }_{1.5}$ and the reference group (SV) are statistically significant at least at $5 \%$ level for variables 'Mean job status of parents', 'Years of education', 'High-status tertiary education', 'Average job status of contacts' and 'income'. Other differences are not statistically significant.

Table 2 demonstrates that, even if the socioeconomic backgrounds of men and women in this sample are nearly equal, men are more likely to have a highstatus tertiary degree and earn higher salaries.

Furthermore, descriptive statistics show that the education of parents of respondents with different immigrant backgrounds is almost the same as that of the SV group, but parents born in ONW countries have lower-status jobs. Children of immigrants born in ONW countries are likely to be less evident among those with university degrees in prestigious programs, to have less social capital and to have lower monthly wages.

\subsection{Access to Objectified State of Social Capital}

To explore the factors that contribute to the distribution of objectified social capital, a series of regression analyses has been estimated with this variable as the dependent variable. As presented in Table 3, the socioeconomic background of respondents has a positive and significant impact on access to objectified social capital. Having a university degree and credentials from a high-status program is also associated with more resources in an individual's social network. The same positive impact holds for age.
Being female (rather than being male) is negatively associated with access to social capital in this sample. For those from immigrant backgrounds, there is a modest and non-significant negative association between being a member of the $\mathrm{NW}_{2}$ or the $\mathrm{ONW}_{2}$ group and having greater social capital. This negative relationship is excessive and significant in the case of the $\mathrm{ONW}_{1.5}$ group. A possible explanation is that the $\mathrm{NW}_{2}$ and $\mathrm{ONW}_{2}$ groups and their parents have lived in Sweden for a longer period of time than the $\mathrm{ONW}_{1.5}$ group. The non-significant effect for the $\mathrm{NW}_{2}$ and $\mathrm{ONW}_{2}$ groups may also reflect the small number of individuals in these groups or the specification of this dataset. As expected, the age of respondents is equally important, because the older respondents are more educated or have additional years of labour market experiences, which potentially enhance their access to more social capital (see also Flap and Boxman [4]).

The effect of active membership of voluntary organizations on access to more objectified social capital is investigated in Model 4. The result demonstrates that active participation in organizations is a positive and significant factor for access to well-resourced networks [47]. 
Table 3. Access to objectified state of social capital, OLS regression, partial (and standardized) coefficients, $\mathrm{N}=438$.

\begin{tabular}{|c|c|c|c|c|}
\hline & Model 1 & Model 2 & Model 3 & Model 4 \\
\hline Socioeconomic background & $\begin{array}{c}\mathbf{0 . 4 6 * * *} \\
(0.46)\end{array}$ & $\begin{array}{c}\mathbf{0 . 2 7} * * * \\
(0.27)\end{array}$ & $\begin{array}{c}\mathbf{0 . 2 6 * * *} \\
(0.26)\end{array}$ & $\begin{array}{c}\mathbf{0 . 2 3} * * * \\
(0.23)\end{array}$ \\
\hline \multicolumn{5}{|l|}{ Education level (secondary ref.) } \\
\hline University degree & & $\begin{array}{c}\mathbf{0 . 8 6} * * * \\
(0.43)\end{array}$ & $\begin{array}{c}\mathbf{0 . 8 6 * * *} \\
(0.43)\end{array}$ & $\begin{array}{c}\mathbf{0 . 8 4} * * * \\
(0.42)\end{array}$ \\
\hline High status tertiary degree & & $\begin{array}{c}\text { 1.12*** } \\
(0.44)\end{array}$ & $\begin{array}{c}\text { 1.01*** } \\
(0.40)\end{array}$ & $\begin{array}{c}\mathbf{0 . 9 6 * * *} \\
(0.38)\end{array}$ \\
\hline Age & & $\begin{array}{c}\text { 0.026** } \\
(0.12)\end{array}$ & $\begin{array}{c}\mathbf{0 . 0 2 6} * * * \\
(0.12)\end{array}$ & $\begin{array}{c}\mathbf{0 . 0 2 3} * * \\
(0.11)\end{array}$ \\
\hline Female & & & $\begin{array}{c}-0.20 * * * \\
(-0.10)\end{array}$ & $\begin{array}{c}-0.20 * * * \\
(-0.10)\end{array}$ \\
\hline \multicolumn{5}{|l|}{ Birthplace (SV ref.) } \\
\hline $\mathrm{NW}_{2}$ & & & $\begin{array}{l}-0.10 \\
(-0.03)\end{array}$ & $\begin{array}{l}-0.10 \\
(-0.03)\end{array}$ \\
\hline $\mathrm{ONW}_{2}$ & & & $\begin{array}{c}-0.03 \\
(-0.007)\end{array}$ & $\begin{array}{c}-0.02 \\
(-0.005)\end{array}$ \\
\hline $\mathrm{ONW}_{1,5}$ & & & $\begin{array}{c}-\mathbf{0 . 6 9} * * * \\
(-0.20)\end{array}$ & $\begin{array}{c}-\mathbf{0 . 6 9} * * * \\
(-0.20)\end{array}$ \\
\hline Voluntary association activity & & & & $\begin{array}{c}\mathbf{0 . 3 3} * * * \\
(0.14) \\
\end{array}$ \\
\hline $\mathrm{R}^{2}$ adj. & 0.22 & 0.48 & 0.53 & 0.54 \\
\hline
\end{tabular}

Note: $* * *$ denotes significance at $1 \%$ level and $* *$ at $5 \%$ level.

\subsection{Wages as a Proxy for Status Attainment}

The last analytical task is to assess the impact of social capital on the (logged) monthly salaries of respondents as a proxy for their status. As mentioned above, the wage gap between different categories of employment for young people is not great in the first phase of their labour market careers. The wage divergence accelerates in the later phases. Furthermore, when considering such an outcome, we should bear in mind that the Swedish wage structure, in general, has been "one of the most compressed in the OECD" ([48], p. 510).

The first model in Table 4 assesses the effect of demographic variables, that is, gender and immigrant background, on young graduates' salaries. Being female generates a lower wage (15 percent) than being male. Being a descendant of immigrants is also associated with a lower wage than being born to natives (by 3,12 and 42 percent). These effects are however not statistically significant for the $\mathrm{NW}_{2}$ and $\mathrm{ONW}_{2}$ groups.

In the second model in Table 4 the socioeconomic background variable is added to the equation, which indicates a positive and significant association between belonging to a higher class and earning a higher wage.

In the third model the effect of 'education' variables is examined. Having a university degree or a degree from a prestigious tertiary program shows a significant and positive association with earning a higher wage. Given the respondents' educational level, the impact of age on salary is non-significant.

The addition of education variables reduces the coefficients for immigrant and class backgrounds, which indicates that part of the wage differences is due to the lower educational attainment of the descendants of immigrants.

In the last model in Table 4, the two indicators of social capital are incorporated into the wage equation (objectified and institutionalised social capital). Social capital variables demonstrate a significant and positive association with higher wages. Social capital seems to be a significant contributing factor to earning a higher wage, even after education and other variables are controlled. 
Table 4. Determinants of (LN) monthly salary, OLS regression, partial (and standardized) coefficients, $\mathrm{N}=438$.

\begin{tabular}{|c|c|c|c|c|}
\hline & Model 1 & Model 2 & Model 3 & Model 4 \\
\hline Female & $\begin{array}{l}-0.15 * * * \\
(-0.18)\end{array}$ & $\begin{array}{c}-0.14 * * * \\
(-0.17)\end{array}$ & $\begin{array}{c}-0.14 * * * \\
(-0.17)\end{array}$ & $\begin{array}{c}-0.12 * * * \\
(-0.14)\end{array}$ \\
\hline \multicolumn{5}{|l|}{ Birthplace (SV ref.) } \\
\hline $\mathrm{NW}_{2}$ & $\begin{array}{l}-0.03 \\
(-0.02)\end{array}$ & $\begin{array}{l}-0.01 \\
(-0.01)\end{array}$ & $\begin{array}{l}-0.01 \\
(-0.01)\end{array}$ & $\begin{array}{l}-0.001 \\
(-0.001)\end{array}$ \\
\hline $\mathrm{ONW}_{2}$ & $\begin{array}{l}-0.12 \\
(-0.07)\end{array}$ & $\begin{array}{l}-0.08 \\
(-0.04)\end{array}$ & $\begin{array}{l}-0.006 \\
(-0.03)\end{array}$ & $\begin{array}{l}-0.002 \\
(0.001)\end{array}$ \\
\hline $\mathrm{ONW}_{1,5}$ & $\begin{array}{c}-0.42 * * * \\
(-0.31)\end{array}$ & $\begin{array}{c}-0.36 * * * \\
(-0.27)\end{array}$ & $\begin{array}{c}-0.27 * * * \\
(-0.20)\end{array}$ & $\begin{array}{c}-0.19 * * * \\
(-0.14)\end{array}$ \\
\hline Socioeconomic background & & $\begin{array}{c}0.12 * * * \\
(0.31)\end{array}$ & $\begin{array}{c}0.03 * * \\
(0.09)\end{array}$ & $\begin{array}{l}0.005 \\
(0.01)\end{array}$ \\
\hline \multicolumn{5}{|l|}{ Education level (Secondary ref.) } \\
\hline University degree & & & $\begin{array}{c}0.36 * * * \\
(0.45)\end{array}$ & $\begin{array}{c}0.24 * * * \\
(0.31)\end{array}$ \\
\hline High-status tertiary degree & & & $\begin{array}{c}0.60 * * * \\
(0.61)\end{array}$ & $\begin{array}{c}0.47 * * * \\
(0.47)\end{array}$ \\
\hline Age & & & $\begin{array}{l}0.006 \\
(0.07)\end{array}$ & $\begin{array}{l}0.002 \\
(0.03)\end{array}$ \\
\hline Objectified state of social capital & & & & $\begin{array}{c}0.12 * * * \\
(0.30)\end{array}$ \\
\hline $\begin{array}{l}\text { Institutionalised state of social } \\
\text { capital }\end{array}$ & & & & $\begin{array}{c}0.12 * * * \\
(0.12)\end{array}$ \\
\hline $\mathrm{R}^{2}$ adj. & 0.13 & 0.22 & 0.55 & 0.61 \\
\hline
\end{tabular}

Note: $* * *$ denotes significance at $1 \%$ level and $* *$ at $5 \%$ level.

Adding the social capital variables further reduces the coefficients of gender [49], immigrant and class backgrounds. This means that the disadvantage suffered by subordinated groups arises partly from lack of access to networks with valuable resources. Social capital variables also reduce the education coefficients, which may indicate that the economic rewards from education credentials in the labour market depend in part on the social capital of individuals [51].

\section{Summary and Discussion}

Young people of different socioeconomic backgrounds are unequally represented in various levels of the Swedish educational system. Those with well-educated parents with high-status jobs are more likely to have a university degree. Our results also demonstrate that part of the observed wage gap between young people from different class and ethnic back- grounds can be explained by educational variables.

In this study the position-generated method is used to measure the objectified state of social capital. Resources in individuals' networks consist of their contacts not only with extended family members and close friends (strong ties) but also with acquaintances (weak ties).

Active membership of organizations is measured separately in this study as an indicator of the institutionalised state of social capital, both in order to investigate its effect on access to more valuable resources in respondents' networks and its impact on the status of individuals beyond resources in their social networks. These findings confirm our suggestion about the significance of membership in civic associations in the Swedish context. Such membership is both a source of objectified social capital and an aid in terms of career development of the members of subordinated groups. 
Respondents with more favourable socioeconomic backgrounds, with higher educational achievements and with membership of voluntary organizations have access to more objectified social capital. There is evidence in this sample that gender and a stigmatized immigrant background hinder access to objectified social capital. Consequently we can conclude that access to networks with valuable resources is not equally distributed.

Our finding that, even after education and other variables are controlled for, social capital (measured in its objectified and institutionalised states) is a significant contributing factor to having higher status in the labour market, indicates that social capital is a partial mediator between educational attainment and labour market status even in the highly regulated Swedish labour market. This also confirm Bourdieu's ([14], p. 110) assertion that: 'Educational qualifications never function perfectly as currency. They are never entirely separable from their holders', and that an academic degree is 'worth what its holder is worth, economically and socially' ([52], p. 79). As we have observed the value of educational credentials increase or decrease in proportion to the value of their bearer.

When after control for 'human capital' variables, social capital variables are taken into account, the wage difference between males and females decreases. The same goes for the wage gap between young people with various educational backgrounds (as proxy for their class background) and the wage gap between the children of natives and those of stigmatized immigrants (both shrink still further). This means that the labour market disadvantages of young people from subordinated groups partly reflect unequal access to social capital. As was suggested earlier, the benefits of social capital to one group in competitive situations (such as obtaining a job or promotion) actually enable this group to exclude others from access to scarce resources. In other words, in a hierarchically ordered society some individuals are connected to resource-rich networks, while others, because of their lower socioeconomic status, their gender or a stigma of race/ethnicity etc., lack similar access to influential networks [53].

The fact that, after controls have been done for the socioeconomic and demographic background as well as the education of respondents, social capital demonstrates a positive association with the young

\section{References and Notes}

1. Bell D. On meritocracy and equality. The public Interest. 1972;29:29-68.

2. Erikson $\mathrm{R}$, Jonsson JO. Ursprung och utbildning: Social snedrekrytering till högre studier: Huvudbetänkande. Stockholm, Sweden: Fritze; 1993.

3. Lai G, Lin N, Leung S-Y. Network Resources, contact resources, and status attainment. Social net- people's wages, and indicates that social capital is likely to be a significant contributing factor to the process of stratification. In other words, the disadvantaged position of subordinate groups (young females and children of lower social classes and stigmatized immigrants) is not only due to what Loury [54] defines as discrimination in contract (the unequal treatment of individuals on the basis of their subordinated identity in formal transactions, e.g. in the recruitment processes). It is also a consequence of discrimination in contact, which means the unequal treatment of persons on the basis of class, gender and 'ethnic' background in the context of more informal, private spheres of life e.g. friendship or partnership [54].

Since social capital, along with educational credentials, is an essential factor for recent graduates in getting an appropriate job, Jokisaari ([35], p. 186) suggests that 'disadvantaged groups need help to access resources beyond their immediate social circles, such as through the provision of sponsors and mentors in career development and ties to institutions'.

Certain limitations restrict the generalizability of these findings. First of all, our analysis includes only individuals who already have a job, although we know from previous studies that entry into working life is a big problem for some young people, particularly young men from working-class families [55]. Another limitation of this study is the response rate of the survey. Therefore, some estimates may suffer from upward or downward bias.

We need further studies to understand how young people with various backgrounds optimize the benefits from their formal education. The next step is to move beyond measuring resources in a person's social network based on fixed socioeconomic and demographic characteristics. Using qualitative research methods would help us to understand the process of social capital accumulation and the ways such resources transmit and affect social inequalities.

\section{Acknowledgements}

Funding from FAS, The Swedish Council for Working Life and Social Research is gratefully acknowledged. The author also thanks colleagues Anders Neergaard and Erik Olsson and others who read and commented on earlier drafts.

works. 1998;20(2):159-178.

4. Flap H, Boxman E. Getting started: The influence of social capital on the start of the occupational career. In: Lin N, Cook K, Burt RS, editors. Social capital: Theory and research. New York, NY, USA: Aldine de Gruyter; 2001.

5. Marsden PV, Gorman EH. Social Networks, Job Changes, and Recruitment. In: Berg IE, Kalleberg AL, editors. Sourcebook of labor markets: Evolving struc- 
tures and processes. New York, NY, USA: Kluwer Academic; 2001. pp. 467-502.

6. Broady D. Sociologi och epistemologi. Pierre Bourdieus författarskap och den historiska epistemologin. Stockholm, Sweden: HLS Förlag; 1991.

7. Field J. Social capital. 2nd ed. Oxon, UK/New York, NY, USA: Routledge; 2008.

8. Borjas GJ. Labor economics. New York, NY, USA: McGraw-Hill; 1996.

9. Ball S. Class strategies and the education market: The middle classes and social advantage. London, UK: Routledge/Falmer; 2002.

10. Bourdieu P. The state nobility: Elite schools in the field of power. Cambridge, UK: Polity; 1996.

11. Bourdieu P. The social structures of the economy. Oxford, UK: Polity; 2005.

12. Portes A. The Two Meanings of Social Capital. Sociological Forum. 2000;15(1): 1-12.

13. Coleman JS. Social Capital in the Creation of Human Capital. American Journal of Sociology. 1988;94:95-120.

14. Bourdieu P. The forms of capital. The sociology of economic life. Boulder, CO, USA/Oxford, UK: Westview Press; 2001.

15. Portes A. Social capital: Its origins and applications in modern sociology. Annual Review of Sociology. 1998;24:1-12.

16. Lin N. Social capital: A theory of social structure and action. Cambridge, UK/New York, NY, USA: Cambridge University Press; 2001.

17. Lin N. A Network Theory of Social Capital. In: Van Deth JW, Castiglione D, Wolleb G, editors. The Handbook of Social Capital. Oxford, UK: Oxford University Press; 2008.

18. Brown $P$, Hesketh $A$. The mismanagement of talent: Employability and jobs in the knowledge economy. Oxford, UK/New York, NY, USA: Oxford University Press; 2004.

19. Erickson BH. Good networks and good jobs. In: N Lin, Cook K, Burt RS, editors. Social capital: Theory and research. New York, NY, USA: Aldine de Gruyter; 2001.

20. Granovetter MS. Getting a job: A study of contacts and careers. Cambridge, MA, USA: Harvard University press; 1974.

21. Brown P, Hesketh AJ, Williams S. Employability in a knowledge-driven economy. Journal of Education and Work. 2003;16(2):107-126.

22. Song L, Lin N. Social capital and health inequality: Evidence from Taiwan. Journal of Health and Social Behavior. 2009:50(2):149-163.

23. Denord F, Hjellbrekke J, Korsnes O, Lebaron F, Le Roux B. Social capital in the field of power: The case of Norway. The Sociological Review. 2011;59 (1):86-108.

24. Jenkins R. Racism and recruitment: Managers, organisations, and equal opportunity in the labour market. Cambridge, UK: Cambridge University Press; 1986.
25. The embodied state of social capital is hard to measure using methods other than participant observation.

26. Burt RS. Structural holes: The social structure of competition. Cambridge, MA, USA: Harvard University Press; 1992.

27. Lin N, Erickson BH. Social Capital: An International Research Program. Oxford, UK: Oxford University Press; 2008.

28. Bourdieu $P$, Wacquant LJD. An invitation to reflexive sociology. Cambridge, UK: Polity; 1992.

29. Arneil B. Diverse communities: The problem with social capital. Cambridge, UK: Cambridge University Press; 2006.

30. Mulinari D. Women friendly? Understanding gendered racism in Sweden. In: Melby K, Ravn A-B, Wetterberg CC, editors. The Limits of Political Ambition? Gender Equality and Welfare Politics in Scandinavia. Bristol, UK: Policy Press; 2008. pp. 167-182.

31. Wang Y. The Effects of Cumulative Social Capital on Job Outcomes of College Graduates. PhD Thesis. Blacksburg, VA, USA: Virginia Polytechnic Institute; 2008.

32. Lin N. Access to Occupations through Social Ties. Social Networks. 1986;8(4):365-385.

33. Lin N, Erickson BH. Theory, Measurement, and the Research Enterprise on Social Capital. In: Lin N, Erickson BH, editors. Social Capital: An International Research Program. Oxford, UK: Oxford University Press; 2008.

34. Cain GG. The Economic Analysis of Labor Market Discrimination: A Survey. In: Layard R, Ashenfelter $\mathrm{O}$, editors. Handbook of labor economics. Amsterdam, The Netherlands: Elsevier Science Publishers BV; 1986.

35. Jokisaari M. From Newcomer to insider? Social networks and socialisation into working life. In: Helve $\mathrm{H}$, Bynner J, editors. Youth and Social Capital. London, UK: Tufnell Press; 2007.

36. Jokisaari M, Nurmi J-E. Company matters: Goalrelated social capital in the transition to working life. Journal of Vocational Behavior. 2005;67(3):413-428.

37. Approximately 98 percent of those who leave compulsory schools in Sweden move on to upper secondary schools. Both vocational and academic courses at this level take three years. The 14 vocationallyoriented courses, which involve the students working, at least 15 percent of the time in the workplace, prepare pupils for the labour market but also offer the possibility of enrolling in higher education.

38. Reay D, David ME, Ball SJ. Degrees of choice: Social class, race, and gender in higher education. Stoke-on-Trent, UK: Trentham Books; 2005.

39. Berggren C. Horizontal and vertical differentiation within higher education-Gender and class perspectives. Higher Education Quarterly. 2008;62(1-2): 20-39.

40. Löfgren Martinsson M. Högre utbildning och arbete med personal- och arbetslivsfrågor - om professionalisering och utveckling av anställningsbarhet. 
Lund, Sweden: Pedagogiska institutionen, Lund University; 2008.

41. Berr D. Öppna jämförelser 2011. Gymnasieskola. Stockholm, Sweden: Sveriges kommuner och landsting; 2011.

42. Bradley $H$, Devadason R. Fractured transitions: Young adults' pathways into contemporary labour markets. Sociology. 2008;42(1):119-136.

43. Portes A, Rumbaut RG. Legacies: The story of the immigrant second generation. Berkeley, CA, USA: University of California Press; 2001.

44. Countries defined as NW in this study are: Denmark, Finland, Norway, Ireland, UK, France, Italy, Germany, Netherlands, Belgium, Spain, Austria, Ireland, Luxembourg, Switzerland, Japan, Canada, Australia, New Zealand and the United States. The rest of the world is defined as ONW.

45. Özcan, G. Essays on labor market disparities and discrimination: Imigration, education and gender. PhD Thesis. Stockholm, Sweden: Department of Economics, Stockholm University; 2001. p. 27s.

46. To select the occupations in this list I followed Lin and Erickson ([27], p. 9) who suggest: "choose occupations from different sectors of the economy, to represent some horizontal as well as vertical differences in occupational resources. It is important to choose occupations with clear, widely understood titles that appear in the society's census".

47. Here we have assumed that active membership of a voluntary association increases the valuable resources in one's social network, thereby creating more objectified social capital. Given the cross-sectional nature of the data, it is impossible to verify the causal sequence between the two variables. Therefore we should not rule out the possibility that the objectified state of social capital enhances voluntary association activity.

48. Granqvist $L$, Regnér $H$. Decentralized wage formation in Sweden. British Journal of Industrial Relations. 2008;46(3):500-520.

49. In the case of women in this sample we have found that after including all control variables in Model 4 a wage gap of 12 percent remains. This gap is likely to be the result of other mechanisms, like gender discrimination and the high level of gender segregation in the Swedish labour market [50].

50. Gonäs L, Karlsson JC. Gender segregation: Divisions of work in post-industrial welfare states. Burlington, VT, USA: Ashgate; 2006.

51. All dependent variables in Table 3 and Table 4 were tested for multicolinearity before inclusion in the models.

52. Bourdieu P, Passeron JC. The inheritors: French students and their relation to culture. Chicago, IL, USA: University of Chicago Press; 1979.

53. Moren-Cross JL, Lin N. Access to social capital and status attainment in the United States: Racial/ ethnic and gender differences. In: Lin N, Erickson $\mathrm{BH}$, editors. Social capital: An international research program. Oxford, UK/New York, NY, USA: Oxford University Press; 2008. pp. 364-379.

54. Loury GC. The anatomy of racial inequality. Cambridge, MA, USA: Harvard University Press; 2002.

55. McDowell L. Redundant masculinities? Employment change and white working class youth. Oxford, UK: Blackwell; 2003. 
Table A1. Summary of position-generated indexes and position generator in the sample.

\begin{tabular}{|c|c|}
\hline \multicolumn{2}{|l|}{ Variables, mean } \\
\hline Extensity (number of positions accessed) & 8.4 \\
\hline Upper reachability (prestige of highest accessed position) & 70.5 \\
\hline Range of prestige & 47.2 \\
\hline Average positions accessed & 46.5 \\
\hline \multicolumn{2}{|l|}{ Accessed positions (prestige score) $\%$} \\
\hline Medical doctor (89) & 43.2 \\
\hline Lawyer (87) & 21.2 \\
\hline Civil engineer (81) & 59.3 \\
\hline Local politician (66) & 25.0 \\
\hline Journalist (66) & 27.1 \\
\hline Police officer (63) & 41.9 \\
\hline Local government official (56) & 41.3 \\
\hline Secondary schoolteacher (55) & 43.9 \\
\hline Nurse (52) & 63.8 \\
\hline Primary schoolteacher (48) & 65.5 \\
\hline Foreman (42) & 47.6 \\
\hline Librarian (40) & 16.3 \\
\hline Office clerk (37) & 44.9 \\
\hline Farmer (36) & 42.2 \\
\hline Childcare workers in kindergarten (35) & 51.9 \\
\hline Machinery worker (33) & 58.4 \\
\hline Assistant nurse (32) & 64.7 \\
\hline Cook (31) & 51.5 \\
\hline Shop assistant (27) & 59.3 \\
\hline Cleaner (16) & 32.8 \\
\hline Dishwasher (8) & 8.9 \\
\hline
\end{tabular}

